\title{
Peptides derived from the HIV-1 integrase promote HIV-1 infection and multi-integration of viral cDNA in LEDGF/p75-knockdown cells
}

\author{
Aviad Levin, Zvi Hayouka², Assaf Friedler², Abraham Loyter ${ }^{\text {** }}$
}

\begin{abstract}
Background: The presence of the cellular Lens Epithelium Derived Growth Factor p75 (LEDGF/p75) protein is essential for integration of the Human immunodeficiency virus type 1 (HIV-1) cDNA and for efficient virus production. In the absence of LEDGF/p75 very little integration and virus production can be detected, as was demonstrated using LEDGF/p75-knokdown cells.

Results: Here we show that the failure to infect LEDGF/p75-knockdown cells has another reason aside from the lack of LEDGF/p75. It is also due to inhibition of the viral integrase (IN) enzymatic activity by an early expressed viral Rev protein. The formation of an inhibitory Rev-IN complex in virus-infected cells can be disrupted by the addition of three IN-derived, cell-permeable peptides, designated INr (IN derived-Rev interacting peptides) and INS (IN derived-integrase stimulatory peptide). The results of the present work confirm previous results showing that HIV-1 fails to infect LEDGF/p75-knockdown cells. However, in the presence of INrs and INS peptides, relatively high levels of viral cDNA integration as well as productive virus infection were obtained following infection by a wild type (WT) HIV-1 of LEDGF/p75-knockdown cells.

Conclusions: It appears that the lack of integration observed in HIV-1 infected LEDGF/p75-knockdown cells is due mainly to the inhibitory effect of Rev following the formation of a Rev-IN complex. Disruption of this inhibitory complex leads to productive infection in those cells.
\end{abstract}

\section{Background}

Productive infection of susceptible cells by Human immunodeficiency virus type 1 (HIV-1) has been shown to require, in addition to virus-encoded proteins, the presence of the host cellular protein Lens Epithelium Derived Growth Factor p75 (LEDGF/p75) [1-3]. Following nuclear import of a viral integrase (IN)-DNA complex, IN interacts with intranuclear LEDGF/p75 molecules, which pave its way via the recipient cells chromatin allowing efficient integration [1,4-6]. This is mediated by the LEDGF/p75 AT hook and PWWP domains [7-9]. The requirement for LEDGF/p75 was demonstrated by experiments showing a lack of integration, and thus virus production, in LEDGF/p75-

\footnotetext{
* Correspondence: loyter@cc.huji.ac.il

'Department of Biological Chemistry, The Alexander Silberman Institute of Life Sciences; The Hebrew University of Jerusalem, Safra Campus, Givat Ram, Jerusalem 91904, Israel

Full list of author information is available at the end of the article
}

knockdown cells $[4,6,10,11]$. Moreover, expression of the LEDGF/p75 integrase-binding domain (IBD), which mediates the LEDGF/p75 binding to IN, was shown to significantly inhibit integration and virus infection due to its ability to interfere with the IN-LEDGF/p75 interaction [12]. Finally, HIV strains bearing mutated IN proteins which fail to interact with LEDGF/p75 are not infectious [13]. These results demonstrate that the presence of intracellular LEDGF/p75 protein is essential for efficient virus infection. However, integration of HIV-1 cDNA can occur in LEDGF/p75-knockdown cells following infection with HIV-1 mutant lacking the Rev protein ( $\Delta \operatorname{Rev}$ virus), as has been shown previously by us [14].

Following integration of the viral cDNA, several viral proteins are expressed, among them Rev [15]. After its nuclear import the Rev protein is involved in nuclear export of unspliced and partially spliced viral RNA molecules [15]. Thus, similar to IN, the presence the 
Rev protein is essential for completion of the HIV-1 life cycle [15]. In addition to its expression from integrated viral DNA, Rev can be expressed from unintegrated DNA molecules and thus appear at an early stage in virus-infected cells [16-20]. Recently, we have shown that early expressed Rev can interact with IN in virusinfected cells, resulting in inhibition of IN nuclear import $[18,21]$ as well as of its enzymatic activity $[17,22,23]$. Rev-induced inhibition of the IN enzymatic activity resulted in inhibition of cDNA integration and significant reduction in the degree of virus infection $[14,17,24]$. Formation of the Rev-IN complex in virusinfected cells can be disrupted by three cell-permeable IN-derived peptides, the INrs (IN derived-Rev interacting peptides) [22] and INS (IN derived-integrase stimulatory peptide) [25]. The INS, in addition to its ability to promote dissociation of the Rev-IN complex, was able to stimulate the enzymatic activity of the IN itself in vitro, and consequently the integration of viral cDNA in virus infected cells [25].

In the current work we show that in the presence of the INr and INS peptides, WT HIV-1 can productively infect LEDGF/p75-knockdown cells. Furthermore, a relatively high degree of viral cDNA integration was observed in these cells following their incubation with the INr and INS peptides. These results indicate that the previously reported $[4,6,10,11]$ failure of the HIV-1 to infect LEDGF/p75-knockdown is mainly due to the formation of the inhibitory Rev-IN complex.

\section{Results}

The INS peptide binds to LEDGF/p75 and partially disrupts the IN-LEDGF/p75 complex

The INS peptide was derived from the IN domain that mediates IN binding to Rev [25] as well as IN-IN interactions [26]. This peptide stimulates IN enzymatic activity in vitro and integration of the viral genome in HIV-1infected cells [25]. Based on structural studies, it appears that binding of the IN to the LEDGF/p75 protein is also mediated by the same domain [2]. It was therefore of interest to determine whether the INS peptide, in addition to its binding to IN and Rev, is also able to interact with the LEDGF/p75 protein. ELISA binding studies revealed specific binding of INS to LEDGF/p75 (Fig. 1A and Table 1). The same was observed with two modified INS peptides (INS K188E and K188A [25]). The results in Fig. $1 \mathrm{~B}$ and $1 \mathrm{C}$ show that the INS and its two derived peptides caused in vitro only partial inhibition of the INLEDGF/p75 interaction. Being cell permeable [25], these peptides were able to cause partial disruption of the INLEDGF/p75 complex formed in virus infected cells as was revealed by co-immunoprecipitation (Co-IP) experiments of an extract obtained from HIV-infected cells (Fig. 1D).

\section{The INS peptide promotes HIV-1 CDNA integration in LEDGF/p75-knockdown cells}

The results in Fig. 2A and Table 2 confirm previous observations $[4,6,10,11]$ of almost no detectable viral cDNA integration in LEDGF/p75-knockdown cells (HeLaP4/shp75Cl15 cells [27]) infected by a WT HIV-1 (in this case at a multiplicity of infection (MOI) of 1.0). On the other hand, when the LEDGF/p75-knockdown cells were infected by a $\Delta$ Rev HIV-1 at the same MOI, an average of about 4 integration events were observed per cell (Fig. 2A and Table 2, and see also Levin et al. [14]). These integration levels were greatly stimulated by the addition of increasing amounts of the INS peptide (Fig. 2A and Table 2). Such stimulation of integration was observed in LEDGF/p75-knockdown cells as well as in WT HeLa P4 cells infected with the WT or $\Delta$ Rev viruses (Fig. 2A and Table 2). As many as 11.0 integration events in average per cell were observed when LEDGF/p75-knockdown cells were infected with WT virus at a MOI of 1.0 in the presence of $200 \mu \mathrm{M}$ INS. However, when these cells were infected under the same experimental conditions with the $\Delta R e v$ virus, the integration reached a high value of an average of 17.0 integration events per cell (Fig. 2A and Table 2).

The results in Fig. 2A, show, as was reported previously $[14,17,25]$, that infection of HeLa P4 cells by the WT virus (in the absence of INS) results in only 1.0 integration event (in average) per cell. This value increased to as high as 19.0 integration events (in average) per cell in the presence of $200 \mu \mathrm{M}$ INS and to 30.0 integration events (in average) per cell following infection of the INS-treated HeLa P4 cells with $\Delta$ Rev virus. The degree of viral cDNA integration was directly proportional to the concentrations of the INS added (Fig. 2A). Quantitative analysis of the total amount of viral cDNA in cells infected with WT or $\triangle$ Rev HIV-1, both at a MOI of 1.0, revealed the presence of about 30.0 to 35.0 copies (in average) per cell (Fig. 2B). It appears therefore that a value of 30.0 integration events (in average) per cell-in the case of HeLa P4 cells treated with $200 \mu \mathrm{M}$ INS and infected by a $\Delta$ Rev HIV-1reflects integration of practically all of the available viral cDNA copies. The number of cDNA copies generated (in average) per infected cell are not linearly correlated to the MOI added as was revealed by estimating the amount of viral cDNA copies per cell in cells infected by increasing MOIs (see Additional file 1 and Additional file 2, Fig. S1).

In the absence of INS, practically no integration of viral cDNA was observed in the LEDGF/p75-knockdown cells, even when infected at high MOI (10.0) by the WT HIV-1 (Fig. 3A and Table 3). On the other hand, an increase in the degree of integration was observed the when LEDGF/p75-knockdown cells were infected with 


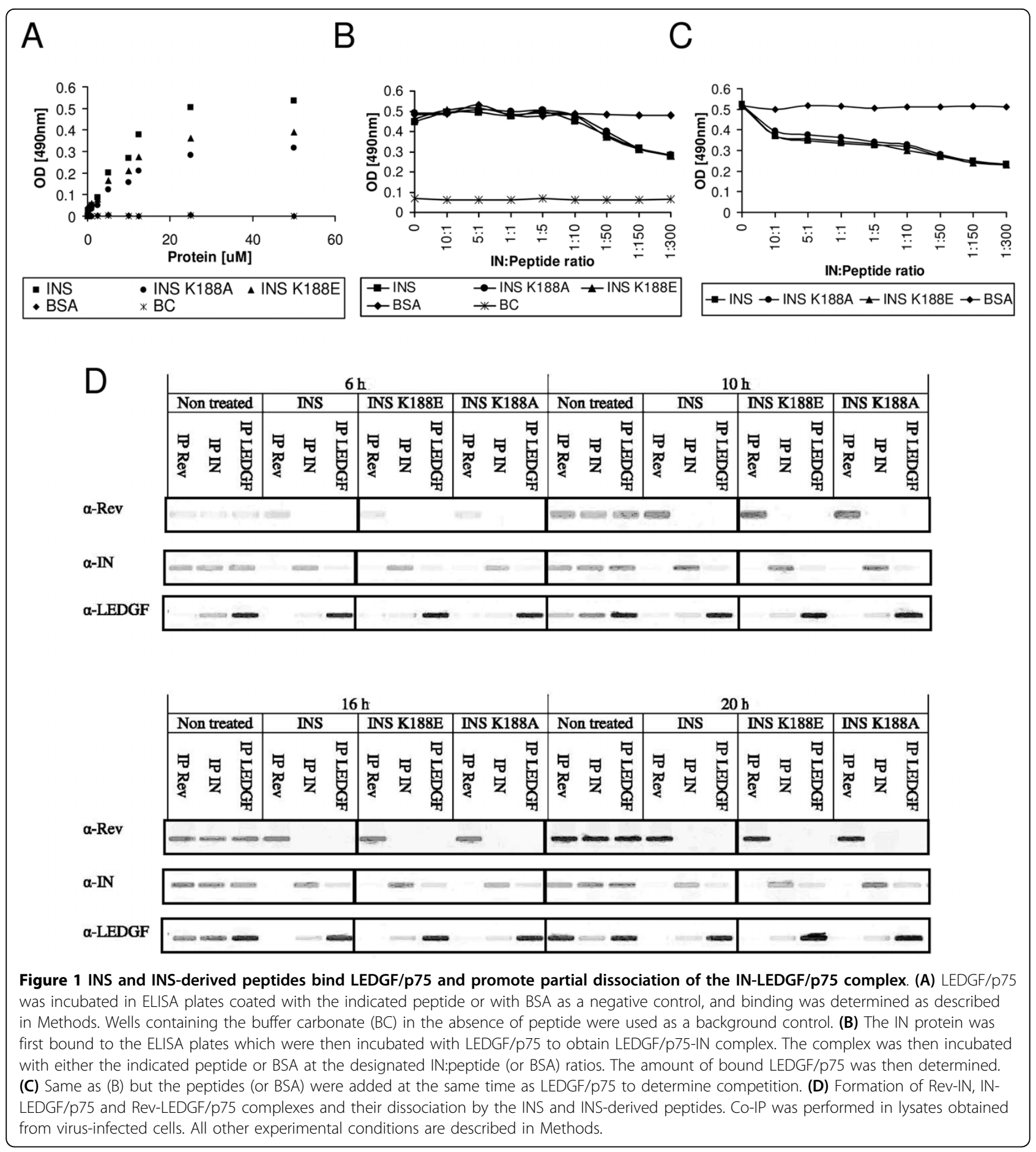

Table 1 Binding to LEDGF/p75

\begin{tabular}{cccc}
\hline & & & LEDGF \\
\cline { 4 - 4 } Peptide & Sequence & IN residues & $\mathbf{K}_{\mathbf{d}}[\boldsymbol{\mu M}]^{*}$ \\
\hline INS & WTAVQMAVFIHNFKRK & W+174-188 & $2.2 \pm 0.7$ \\
INS K188A & WTAVQMAVFIHNFKRA & W+174-187+A & $3.0 \pm 1.5$ \\
INS K188E & WTAVQMAVFIHNFKRE & W+174-187+E & $4.5 \pm 2.0$ \\
\hline
\end{tabular}

${ }^{*}$ Apparent $K_{d}$ according to ELISA system using LEDGF and BSA alone as control. increasing amounts of WT HIV-1, reaching about 7.0 integration events in average per cell at a MOI of 10.0, in the presence of $100 \mu \mathrm{M}$ INS (Fig. 3A and Table 3). The same increase was observed, but to a much higher degree of integration, when WT HeLa P4 cells were infected with increasing amounts of WT HIV-1 in the presence of INS (Fig. 3A and Table 3). A clear 
A

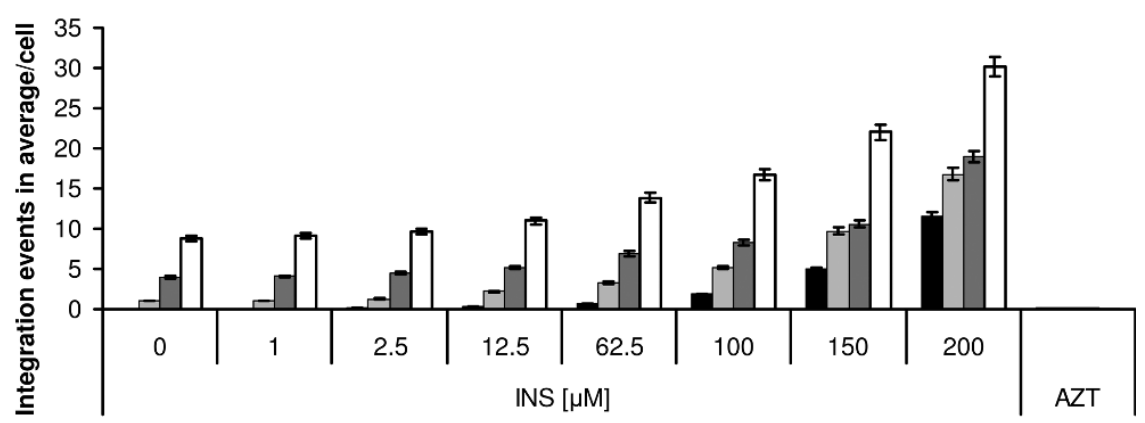

$\mathrm{B}$

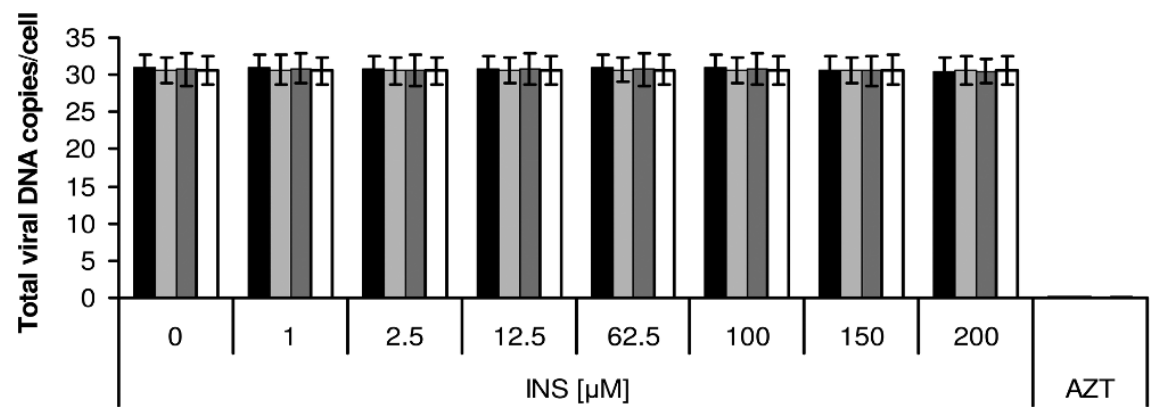

Figure 2 Effect of INS concentrations on integration and total viral-DNA in infected wt and LEDGF/p75-knockdown HeLa-P4 cells. HeLa P4 and HeLaP4/shp75Cl15 (LEDGF/p75-knockdown) cells were incubated with the indicated concentration of INS and infected with wt or $\triangle$ Rev HIV-1 at a $\mathrm{MOI}$ of 1.0. The average number of integration events per cell (A) and of total viral DNA copies per cell (B) was estimated as described in Methods. Black shading and dark grey shading are LEDGF/p75-knockdown cells infected with WT or $\triangle$ Rev HIV-1, respectively; white grey shading and white shading are HeLa P4 cells infected with WT or $\triangle$ Rev HIV-1, respectively. AZT was used at $2 \mu$ M concentration.

correlation between the amount of HIV-1 added and the degree of integration was observed when the same experiments were performed using the $\Delta$ Rev virus (Fig. $3 \mathrm{~B}$ and Table 3 ). As many as 50.0 and 23.0 integration events in average per cell were obtained following infection of WT HeLa P4 and LEDGF/p75-knockdown cells respectively by the $\Delta \operatorname{Rev} \mathrm{HIV}-1$ at a MOI of 10.0 , in the presence of $100 \mu \mathrm{M}$ INS (Fig. 3B and Table 3).

Similar to INS, the INrs are IN-derived peptides which promote dissociation of the Rev-IN complex [17,22,24]. Therefore, in light of the above results, it was of interest to find out whether the INrs would also stimulate integration of viral cDNA in LEDGF/p75-knockdown cells. In contrast to the INS, the INrs do not interact with IN and therefore do not affect its enzymatic activity [22].
From the results presented in Fig. 4 it is clear that the INrs were also able to significantly stimulate integration in LEDGF/p75-knockdown cells, most probably due to their ability to promote dissociation of the intracellular Rev-IN complex $[17,22,24]$. The extent of INr stimulation of integration levels was lower than that obtained by the INS peptide, probably due to their inability to enhance the enzymatic activity of the IN itself [22].

Productive virus infection is greatly stimulated by the INS and INr peptides in LEDGF/p75-knockdown cells

The INS and INr peptides were also able to support high productive virus infection in LEDGF/p75-knockdown cells (Fig. 5), probably due to their ability to promote an increase in viral cDNA integration events in

Table 2 Summary of the results described in Figure 2

\begin{tabular}{|c|c|c|c|c|c|c|c|c|c|}
\hline \multirow[b]{2}{*}{ Cells } & \multirow[b]{2}{*}{ Virus (MOI 1) } & \multicolumn{8}{|c|}{ INS $[\mu \mathrm{M}]$} \\
\hline & & 0 & 1 & 2.5 & 12.5 & 62.5 & 100 & 150 & 200 \\
\hline \multirow[t]{2}{*}{ HeLa P4 } & WT & $1.02 \pm 0.08$ & $1.04 \pm 0.07$ & $1.25 \pm 0.09$ & $2.16 \pm 0.11$ & $3.30 \pm 0.14$ & $5.16 \pm 0.20$ & $9.70 \pm 0.43$ & $18.93 \pm 0.74$ \\
\hline & $\Delta \operatorname{Rev}$ & $8.82 \pm 0.37$ & $9.13 \pm 0.34$ & $9.65 \pm 0.41$ & $10.98 \pm 0.43$ & $13.83 \pm 0.61$ & $16.66 \pm 0.71$ & $21.99 \pm 0.94$ & $30.16 \pm 1.12$ \\
\hline \multirow[t]{2}{*}{ LEDGF/p75-knockdown } & WT & $0.04 \pm 0.01$ & $0.08 \pm 0.01$ & $0.17 \pm 0.02$ & $0.39 \pm 0.03$ & $0.69 \pm 0.05$ & $1.23 \pm 0.10$ & $3.32 \pm 0.14$ & $11.60 \pm 0.57$ \\
\hline & $\Delta \operatorname{Rev}$ & $3.93 \pm 0.17$ & $4.05 \pm 0.21$ & $4.44 \pm 0.27$ & $5.21 \pm 0.38$ & $6.92 \pm 0.47$ & $8.30 \pm 0.63$ & $10.56 \pm 0.74$ & $16.80 \pm 1.01$ \\
\hline
\end{tabular}

Values represent an average number of integrations per cell. 
A

$\mathrm{B}$
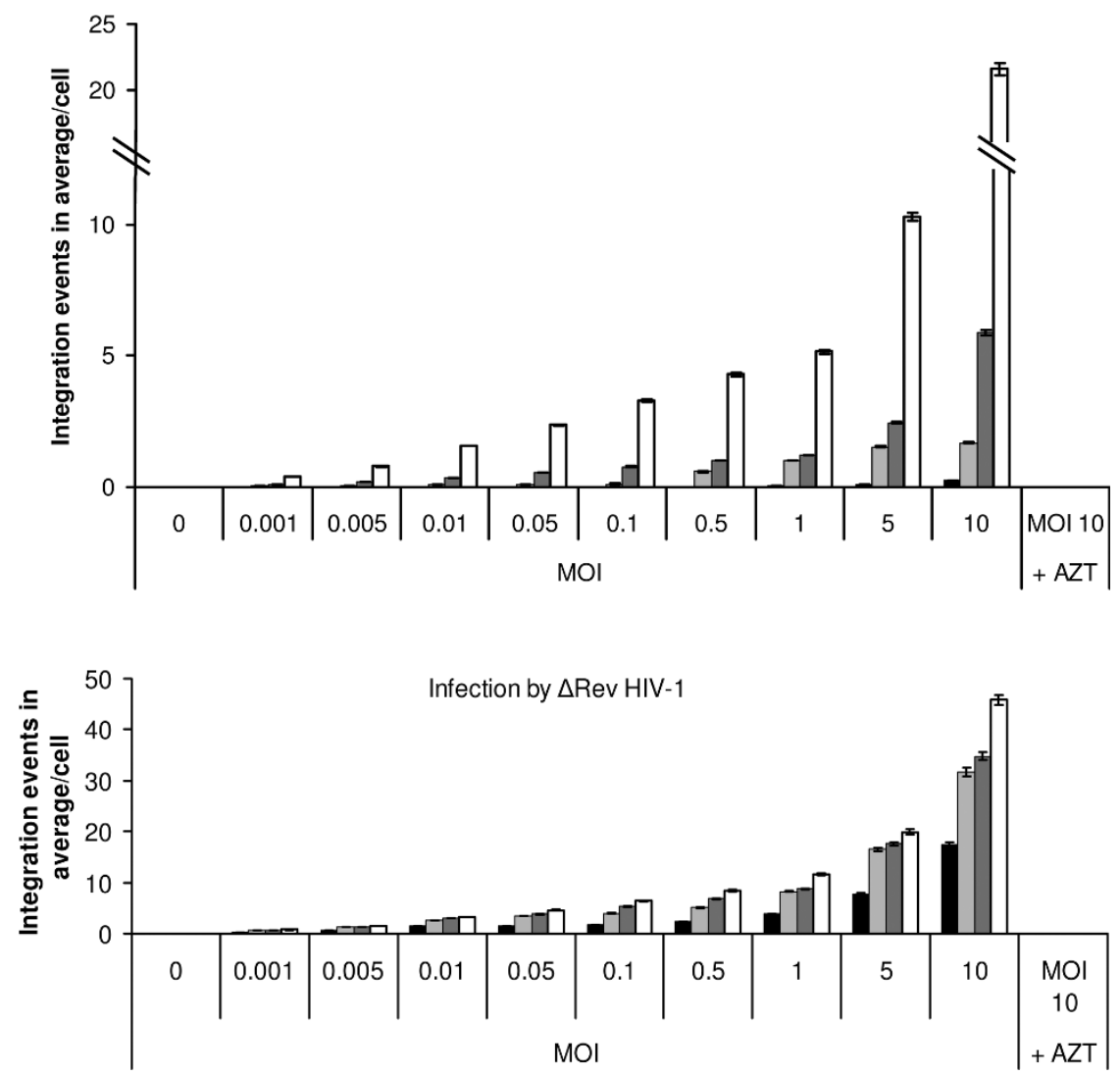

Figure 3 Effect of increasing HIV-1 MOIs on integration levels in infected wt and LEDGF/p75-knockdown HeLa P4 cells. HeLa P4 and HeLaP4/shp75Cl15 (LEDGF/p75-knockdown) cells were incubated with or without $100 \mu \mathrm{M}$ INS and infected at the indicated MOls with (A) WT or (B) $\triangle$ Rev HIV-1. The average number of integration events per cell was estimated as described in Methods. Black shading and dark grey shading are infected LEDGF/p75-knockdown cells without or with INS treatment, respectively; light grey shading and white shading are infected HeLa P4 cells without or with INS treatment, respectively. AZT was used at $2 \mu \mathrm{M}$ concentration.

Table 3 Summary of the results described in Figure 3

\begin{tabular}{|c|c|c|c|c|c|c|c|c|c|c|c|}
\hline \multirow[b]{2}{*}{ Cells and peptides } & \multirow[b]{2}{*}{ Virus } & \multicolumn{10}{|c|}{ MOI } \\
\hline & & 0 & 0.001 & 0.005 & 0.01 & 0.05 & 0.1 & 0.5 & 1 & 5 & 10 \\
\hline \multirow[t]{2}{*}{ HeLa P4 } & WT & 0 & $\begin{array}{l}0.05 \pm \\
0.01\end{array}$ & $\begin{array}{c}0.06 \pm \\
0.01\end{array}$ & $\begin{array}{l}0.09 \pm \\
0.01\end{array}$ & $\begin{array}{l}0.10 \pm \\
0.01\end{array}$ & $\begin{array}{c}0.12 \pm \\
0.01\end{array}$ & $\begin{array}{c}0.51 \pm \\
0.02\end{array}$ & $1.02 \pm 0.08$ & $1.53 \pm 0.09$ & $1.68 \pm 0.11$ \\
\hline & $\Delta \operatorname{Rev}$ & 0 & $\begin{array}{c}0.67 \pm \\
0.04\end{array}$ & $\begin{array}{l}1.34 \pm \\
0.10\end{array}$ & $\begin{array}{l}3.22 \pm \\
0.15\end{array}$ & $\begin{array}{l}3.42 \pm \\
0.16\end{array}$ & $\begin{array}{c}3.95 \pm \\
0.18\end{array}$ & $\begin{array}{l}5.13 \pm \\
0.23\end{array}$ & $8.79 \pm 0.37$ & $\begin{array}{c}17.59 \pm \\
0.89\end{array}$ & $\begin{array}{c}52.76 \pm \\
2.21\end{array}$ \\
\hline \multirow[t]{2}{*}{$\begin{array}{l}\text { LEDGF/p75- } \\
\text { knockdown }\end{array}$} & WT & 0 & 0 & $\begin{array}{c}0.01 \pm \\
0.00\end{array}$ & 0 & 0 & 0 & $\begin{array}{c}0.01 \pm \\
0.00\end{array}$ & $0.04 \pm 0.01$ & $0.08 \pm 0.01$ & $0.23 \pm 0.03$ \\
\hline & $\Delta \operatorname{Rev}$ & 0 & $\begin{array}{l}0.30 \pm \\
0.03\end{array}$ & $\begin{array}{l}0.60 \pm \\
0.04\end{array}$ & $\begin{array}{l}1.43 \pm \\
0.08\end{array}$ & $\begin{array}{l}1.52 \pm \\
0.07\end{array}$ & $\begin{array}{l}1.76 \pm \\
0.09\end{array}$ & $\begin{array}{c}2.28 \pm \\
0.10\end{array}$ & $3.91 \pm 0.13$ & $7.83 \pm 0.47$ & $\begin{array}{c}23.48 \pm \\
1.34\end{array}$ \\
\hline \multirow[t]{2}{*}{$\begin{array}{c}\text { HeLa P4 } \\
+ \text { INS } 100 \mu \mathrm{M}\end{array}$} & WT & 0 & $\begin{array}{c}0.39 \pm \\
0.02 \\
\end{array}$ & $\begin{array}{c}0.78 \pm \\
0.02 \\
\end{array}$ & $\begin{array}{c}1.57 \pm \\
0.09 \\
\end{array}$ & $\begin{array}{c}2.35 \pm \\
0.14 \\
\end{array}$ & $\begin{array}{c}3.30 \pm \\
0.20 \\
\end{array}$ & $\begin{array}{c}4.29 \pm \\
0.35 \\
\end{array}$ & $5.14 \pm 0.44$ & $\begin{array}{c}10.29 \pm \\
0.99 \\
\end{array}$ & $\begin{array}{c}30.86 \pm \\
2.14\end{array}$ \\
\hline & $\Delta \operatorname{Rev}$ & 0 & $\begin{array}{c}0.76 \pm \\
0.03 \\
\end{array}$ & $\begin{array}{c}1.52 \pm \\
0.08 \\
\end{array}$ & $\begin{array}{c}3.04 \pm \\
0.14 \\
\end{array}$ & $\begin{array}{c}4.56 \pm \\
0.38 \\
\end{array}$ & $\begin{array}{c}6.39 \pm \\
0.71 \\
\end{array}$ & $\begin{array}{c}8.30 \pm \\
0.76 \\
\end{array}$ & $\begin{array}{c}11.63 \pm \\
1.01 \\
\end{array}$ & $\begin{array}{c}19.93 \pm \\
1.64 \\
\end{array}$ & $\begin{array}{c}52.37 \pm \\
3.42 \\
\end{array}$ \\
\hline \multirow{2}{*}{$\begin{array}{c}\text { LEDGF/p75- } \\
\text { knockdown } \\
+ \text { INS } 100 \mu \mathrm{M}\end{array}$} & WT & 0 & $\begin{array}{l}0.09 \pm \\
0.01\end{array}$ & $\begin{array}{l}0.19 \pm \\
0.02\end{array}$ & $\begin{array}{l}0.37 \pm \\
0.02\end{array}$ & $\begin{array}{l}0.56 \pm \\
0.03\end{array}$ & $\begin{array}{l}0.78 \pm \\
0.06\end{array}$ & $\begin{array}{l}1.02 \pm \\
0.09\end{array}$ & $1.22 \pm 0.10$ & $2.44 \pm 0.18$ & $7.33 \pm 0.42$ \\
\hline & $\Delta \operatorname{Rev}$ & 0 & $\begin{array}{c}0.63 \pm \\
0.04\end{array}$ & $\begin{array}{c}1.26 \pm \\
0.11\end{array}$ & $\begin{array}{c}2.52 \pm \\
0.18\end{array}$ & $\begin{array}{c}3.79 \pm \\
0.26\end{array}$ & $\begin{array}{c}5.30 \pm \\
0.44\end{array}$ & $\begin{array}{c}6.89 \pm \\
0.61\end{array}$ & $8.27 \pm 0.74$ & $\begin{array}{c}16.54 \pm \\
1.33\end{array}$ & $\begin{array}{c}49.61 \pm \\
3.11\end{array}$ \\
\hline
\end{tabular}

Values represent an average number of integrations per cell. 


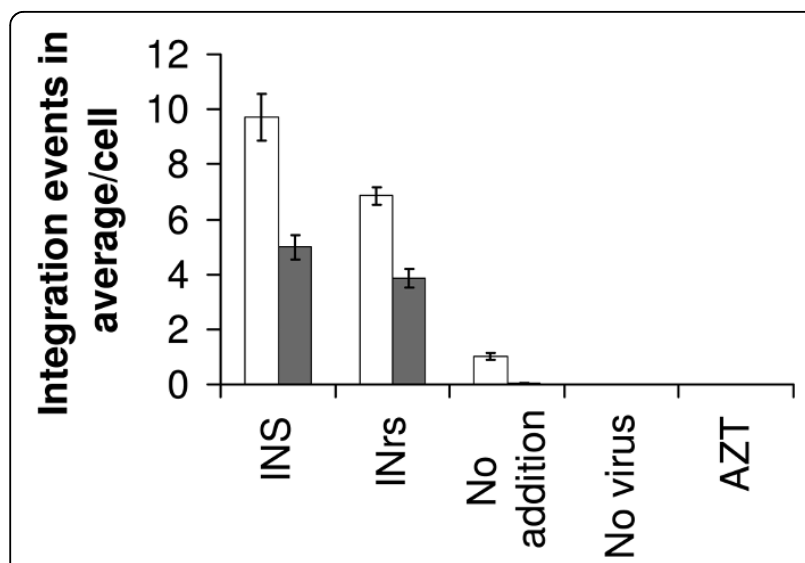

Figure $4 \mathrm{INr}$ peptides stimulate viral CDNA integration in LEDGF/p75-knockdown cells. HeLa P4 (ㅁ) and HeLaP4/shp75Cl15 (LEDGF/p75-knockdown) (-) cells were incubated with or without $100 \mu \mathrm{M}$ INS or INr and infected with wt HIV-1 at a MOI of 1.0. AZT was used at $2 \mu \mathrm{M}$ concentration. The average number of integration events per cell was estimated as described in Methods.

these cells. Production of both p24 (Fig. 5A) and infectious viruses (Fig. 5B) reached, in LEDGF/p75-knockdown cells and in the presence of the INr peptides, the same level as in infected, non-treated, WT HeLa P4 cells (Fig 5). Furthermore, even higher levels of p24 and virus production were obtained following addition of INS to the virus-infected LEDGF/p75-knockdown and wt HeLa P4 cells (Fig. 5A and 5B).

\section{Discussion}

The results of the present work demonstrate that HIV-1 is able to efficiently infect cells which lack the cellular LEDGF/p75 protein, the presence of which is considered to be essential for productive infection $[4,6,10,11]$. However, infection of LEDGF/p75 knockdown cells occurs only in the presence of INS [25] or INr [17,22,24] peptides which promote dissociation of the Rev-IN complex, formed in the infected cells $[14,17,18,22,24]$. Following Rev-IN dissociation viral cDNA integration as well as virus production can reach, in LEDGF/p75knockdown cells, even higher levels than those obtained in WT cells. The fact that viral cDNA integration can occur in LEDGF/p75-knockdown cells provided that the cells are infected by the $\Delta \operatorname{Rev}$ virus has already been demonstrated [14]. These results further supports the view that integration, and consequently infection, in LEDGF/p75-knockdown cells, is blocked by the inhibitory Rev. Infection by the $\Delta$ Rev HIV-1 does not lead to productive infection due to the absence of Rev whose presence is required for nuclear export of unspliced and partially spliced viral RNA molecules [15].

The way by which the interplay between the LEDGF/ p75 and Rev proteins regulates integration of the viral

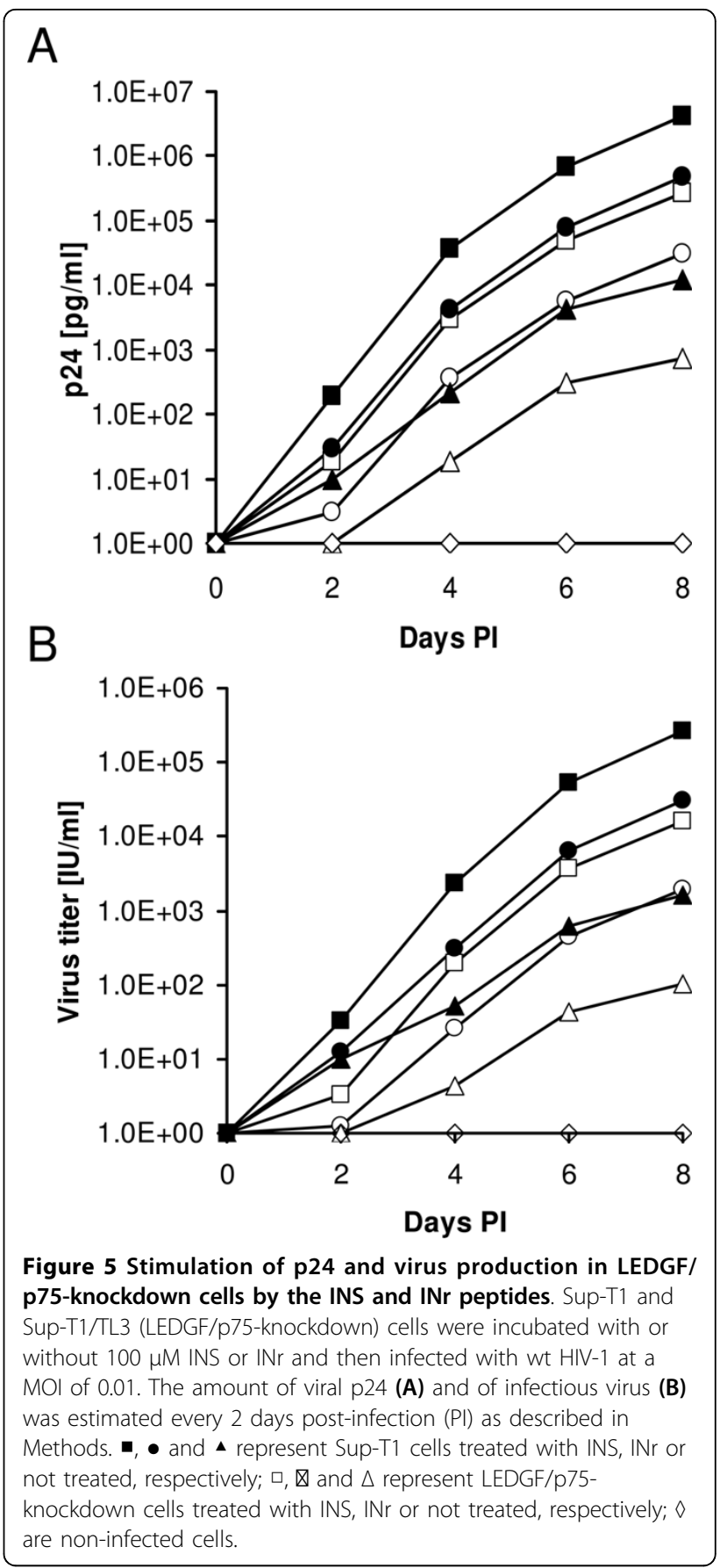

cDNA has been described previously [14]. Infection by HIV-1 results in most cases in the integration of an average of 1 to 2 cDNA molecules per cell $[14,17,22,25,28]$. This is despite the fact that a large number (between 20 and 30 molecules) of cDNA remain unintegrated $[28,29]$. Our previous results $[14,17]$ indicated that this is due to the fact that the large majority of the viral IN molecules, which catalyze the integration reaction, are inactive as a result of their 
interaction with the $\operatorname{Rev}$ protein $[14,17,18,22]$. It is possible, however, that the few integration events that do occur in virus-infected cells are mediated by IN molecules which were translocated, as IN-DNA complexes, into the nucleus before sufficient early Rev was expressed and thus escaped its inhibitory effect $[14,18]$. These active IN molecules then interact with the nucleus-localized LEDGF/p75 protein, which paves the way for the IN-DNA complexes to the host chromosomal DNA $[1,5,13,30]$. From our present results it appears that the resistance of LEDGF/p75-knockdown cells to HIV-1 infection and particularly the absence of any cDNA integration events in such cells is due to the inhibitory effect of Rev $[4,6,10,11]$. Due to the absence of the LEDGF/p75 protein in these cells, all of the IN molecules are available for interaction with Rev, resulting in the formation of inactive Rev-IN complex and complete inhibition of cDNA integaration (Fig. 6A and Levin et al. $[17,18,22])$. Promotion of the Rev-IN complex dissociation by the INr or INS peptides results in reactivation of the IN enzymatic activity, thus allowing relatively efficient integration and virus production in LEDGF/p75-knockdown cells (Fig. 6B).

According to this view, the Rev protein plays a major role in restricting, in WT cells, and totally inhibiting, in LEDGF/p75-knockdown cells, the integration of viral cDNA and consequently virus replication and production. In addition to regulation by Rev, integration is probably regulated by the enzymatic activity of IN itself since stimulation of this activity by INS resulted in further stimulation of integration [25].

\section{Methods}

\section{Protein expression and purification}

Expression and purification of the histidine-tagged IN and LEDGF/p75 expression vectors, were a generous gift from Prof. Engelman, Dana-Farber Cancer Institute and Division of AIDS, Harvard Medical School, Boston, MA, USA), were performed essentially as described previously $[31,32]$.

\section{Peptide synthesis and purification}

Peptides were synthesized on an Applied Biosystems (ABI; Carlsbad, California, USA) 433A peptide synthesizer and purification was performed on a Gilson HPLC using a reverse-phase $\mathrm{C} 8$ semi-preparative column (ACE, Advanced Chromatography Technologies, Aberdeen AB25 1DL, United Kingdom) as described in Levin et al. [22].

\section{ELISA-based binding assays}

Protein-peptide, protein-protein and protein-DNA binding was estimated using an ELISA-based binding assay exactly as described previously [33]. Briefly, Maxisorp

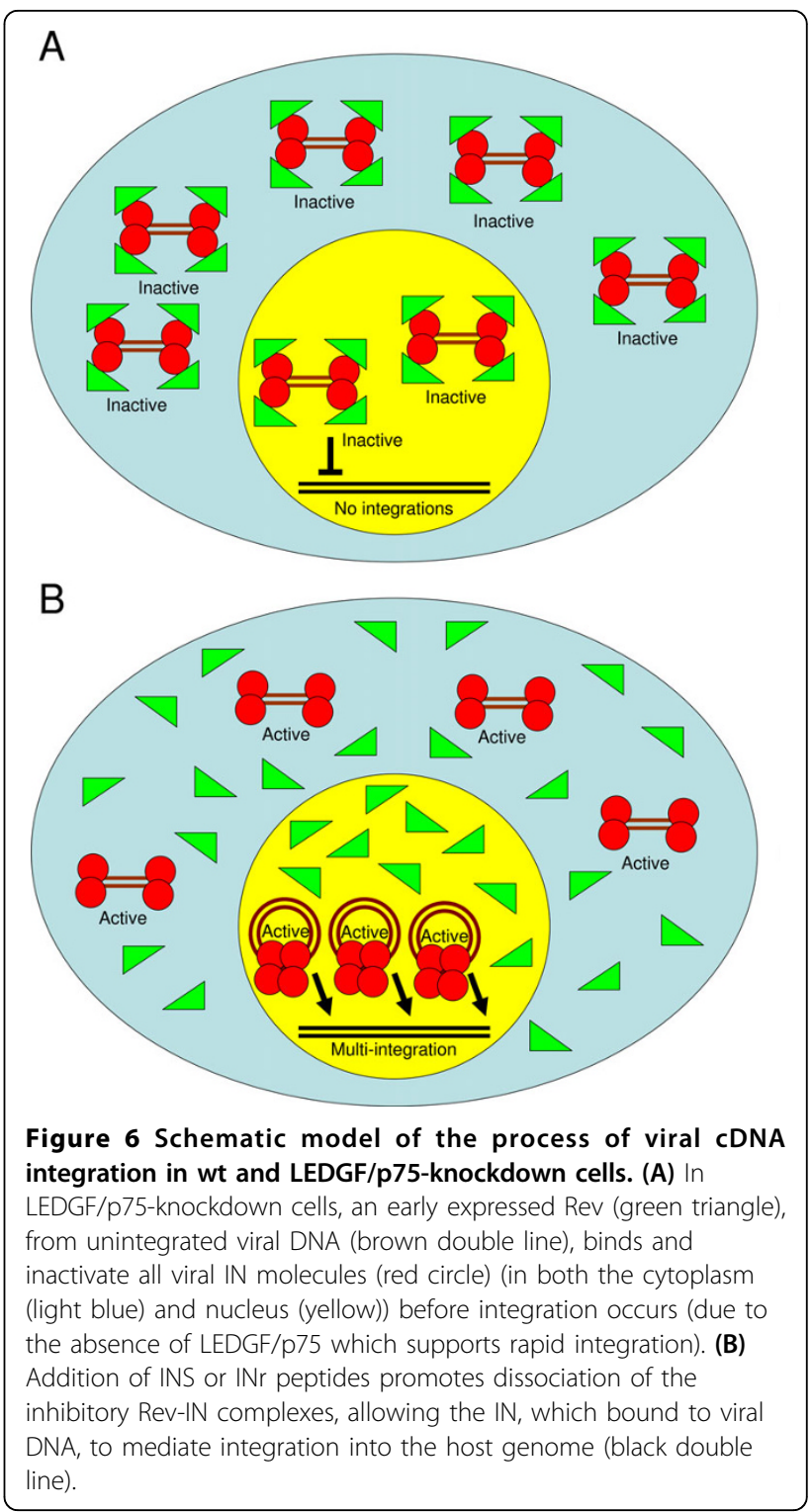

plates (Nunc) were incubated at room temperature for 2 h with $200 \mathrm{ml}$ of $10 \mu \mathrm{g} / \mathrm{ml}$ synthetic peptide/recombinant proteins in carbonate buffer. After incubation, the solution was removed, the plates were washed three times with PBS, and $200 \mu \mathrm{l}$ of $10 \%$ BSA (Sigma) in PBS $(\mathrm{w} / \mathrm{v})$ was added and the plates were further incubated for $2 \mathrm{~h}$ at room temperature. After rewashing with PBS, the tested BSA-biotinilated $(\mathrm{Bb})$ peptide or protein (alone or biotinilated) was added for a further 1-h incubation at room temperature. Following three washes with PBS, the concentration of bound molecules was estimated following the addition of streptavidin-horseradish peroxidase (HRP) conjugate (Sigma), as described previously [34]. The enzymatic activity of HRP was estimated by monitoring the product's optical density (OD) 
at $490 \mathrm{~nm}$ using an ELISA plate reader (Tecan Sunrise, Männedorf, Switzerland). Each measurement was performed in duplicate. Estimation of complex dissociation was performed as follow: after binding of the first protein to the maxisorp plate, the binding partner was incubated for $1 \mathrm{~h}$ at room temperature and after three washes in PBS, the dissociating component was added and its binding to the complex, as well as the remaining bound complex, were estimated separately as described above.

\section{Cells}

Monolayer adherent HEK293T, and HeLa MAGI cells (TZM-bl) [35,36], as well as HEK293T cells over-expressing Rev (Rev10 ${ }^{+}$cells [37]), were grown in Dulbecco's Modified Eagle's Medium (DMEM). The T-lymphocyte cell lines Sup-T1 and Sup-T1/TL3 were grown in RPMI 1640 medium. Cells other than the Rev10 ${ }^{+}, \mathrm{HeLaP} 4 /$ shp75Cl15 and Sup-T1/TL3 cells were provided by the NIH Reagent Program, Division of AIDS, NIAID, NIH (Bethesda, MD, USA). The various cells were incubated at $37^{\circ} \mathrm{C}$ in a $5 \% \mathrm{CO}_{2}$ atmosphere. All media were supplemented with $10 \%(\mathrm{v} / \mathrm{v})$ fetal calf serum, $0.3 \mathrm{~g} / \mathrm{l} \mathrm{L-glu-}$ tamine, $100 \mathrm{U} / \mathrm{ml}$ penicillin and $100 \mathrm{U} / \mathrm{ml}$ streptomycin (Biological Industries, Beit Haemek, Israel). HeLaP4/ shp75Cl15 cells (a generous gift from Prof. Debyser, Molecular Medicine, K.U. Leuven, Flanders, Belgium), were grown as described in Vandekerckhove et al. [27]. Sup-T1/TL3 cells, (a generous gift from Prof. Poeschla Department of Molecular Medicine, Mayo Foundation, Rochester, MN, USA), were grown as described in Llano et al. [5].

\section{Viruses}

The wt HIV-1 (HXB2 [38]) was generated by transfection into HEK293T cells [39]. The $\Delta$ Rev pLAIY47H2 [40] HIV was generated by transfection into Rev $10^{+}$ cells [37]. Viruses were harvested and stored as described previously [22]. The pLAIY47H2 [40] viruses were a generous gift from Prof. Berkhout (Department of Human Retrovirology, Academic Medical Center, University of Amsterdam, The Netherlands). Virus stocks were concentrated by ultracentrifugation $\left(25,000 \mathrm{rpm}\right.$ at $15^{\circ} 388$ for $\left.105 \mathrm{~min}\right)$ using Beckman SW28 rotor [41]. All viral stocks were treated with 50 $\mathrm{U} / \mathrm{ml}$ DNase for $1 \mathrm{~h}$ at $37{ }^{\circ} \mathrm{C}$ in order to eliminate excess of viral DNA plasmid

\section{Infection of cultured lymphocyte cells with HIV-1}

Cultured lymphocytes $\left(1 \times 10^{5}\right)$ were centrifuged for 5 $\mathrm{min}$ at $500 \mathrm{~g}$ and after removal of the supernatant, the cells were resuspended in 0.2 to $0.5 \mathrm{ml}$ RPMI 1640 medium containing virus at different MOIs. Following absorption for $2 \mathrm{~h}$ at $37^{\circ} \mathrm{C}$, the cells were washed to remove unbound virus and then incubated at the same temperature for an additional 2 days [23].

\section{Study of in-vivo protein-protein interactions using the Co-IP methodology}

The Co-IP experiments were conducted essentially as described previously [42] with the following modifications. Briefly, cells were infected at a MOI of 15 of the indicated viruses. Infected cells were harvested at different times post-infection, washed three times with PBS and lysed by the addition of PBS containing $1 \%(\mathrm{v} / \mathrm{v})$ Triton X-100 for whole-cell lysate. Half of the lysate was subjected to SDS-PAGE (an E-PAGE 48 8\% HighThroughput Pre-Cast Gel System (Invitrogen)) and immunoblotted with either monoclonal anti-Rev antibody $(\alpha-\operatorname{Rev})$ [43], antiserum raised against IN amino acids 276-288 $(\alpha-\mathrm{IN})$ (NIH AIDS Research \& Reference Reagent Program catalog number 758), anti-LEDGF/p75 $(\alpha-L E D G F / p 75)(R \& D$ Systems, Minneapolis, MN, USA) or anti-actin ( $\alpha$-Actin) antibody (Santa Cruz), and complementary HRP-conjugated antibodies (Jackson ImmunoResearch, West Grove, PA, USA) as second antibodies.

The remaining lysate was incubated for $1 \mathrm{~h}$ at $4{ }^{\circ} \mathrm{C}$ with either the $\alpha$-Rev, $\alpha$-IN, $\alpha$-LEDGF/p75 or $\alpha$-Actin antibodies. Following 3 -h incubation at $4^{\circ} \mathrm{C}$ with protein G-agarose beads (Santa Cruz Biotechnology, Santa Cruz, CA, USA), the samples were washed three times with PBS containing $1 \%(\mathrm{v} / \mathrm{v})$ Nonidet P-40. SDS buffer was added to the samples and after boiling and SDS-PAGE (an E-PAGE ${ }^{\mathrm{mi}} 48$ 8\% High-Throughput Pre-Cast Gel System (Invitrogen)), the membranes were immunoblotted with either $\alpha$-Rev, $\alpha$-IN, $\alpha$-LEDGF/p75 or $\alpha$ Actin antibodies, and complementary HRP-conjugated antibodies (Jackson) as second antibodies. When peptides were used, cells were incubated with $150 \mu \mathrm{M}$ of the indicated peptide for $2 \mathrm{~h}$ prior to infection.

\section{Quantitative determination of the average copy numbers} of HIV-1 DNA integrated into the cellular genome

The integration reaction was estimated essentially as described previously [23]. Briefly, following incubation of the indicated peptides with Sup-T1 cells for $2 \mathrm{~h}$, the cells were infected at the indicated MOI. Integrated HIV-1 sequences were amplified by two PCR replication steps using the HIV-1 LTR-specific primer (LTR-Tag-F 5'-ATGCCACGTAAGCGAAACTCTGGCTAACTAGGGAACCCACTG-3') and Alu-targeting primers (firstAlu-F 5'-AGCCTCCCGAGTAGCTGGGA-3' and firstAlu-R 5'-TTACAGGCATGAGCCACCG-3') [44]. Alu-LTR fragments were amplified from $10 \mathrm{ng}$ of total cell DNA in a $25-\mu$ l reaction mixture containing $1 \times$ PCR buffer, $3.5 \mathrm{mM} \mathrm{MgCl} 2,200 \mu \mathrm{M}$ dNTPs, $300 \mathrm{nM}$ primers, and $0.025 \mathrm{U} / \mu \mathrm{l}$ of Taq polymerase. The first-round PCR 
cycle conditions were as follows: a DNA denaturation and polymerase activation step of $10 \mathrm{~min}$ at $95^{\circ} \mathrm{C}$ and then 12 cycles of amplification $\left(95^{\circ} \mathrm{C}\right.$ for $15 \mathrm{~s}, 60^{\circ} \mathrm{C}$ for $30 \mathrm{~s}, 72^{\circ} \mathrm{C}$ for $5 \mathrm{~min}$ ).

During the second-round PCR, the first-round PCR product could be specifically amplified using the Tagspecific primer (Tag-F 5'-ATGCCACGTAAGCGAAACTC-3') and the LTR primer (LTR-R 5'-AGGCAAGCTTTATTGAGGCTTAAG-3') designed by PrimerExpress (ABI) using the default settings. The second-round PCR was performed on 1/25th of the firstround PCR product in a mixture containing $300 \mathrm{nM}$ of each primer and $12.5 \mu \mathrm{l} 2 \times$ SYBR Green Master Mix (ABI) at a final volume of $25 \mu \mathrm{l}$, and run on an ABI PRIZM 7700. The second-round PCR cycles began with DNA denaturation and a polymerase-activation step $\left(95^{\circ} \mathrm{C}\right.$ for $\left.10 \mathrm{~min}\right)$, followed by 40 cycles of amplification $\left(95^{\circ} \mathrm{C}\right.$ for $15 \mathrm{~s}, 60^{\circ} \mathrm{C}$ for $\left.60 \mathrm{~s}\right)$.

To generate a standard calibration curve, the SVC21 plasmid containing the full-length HIV-1 $1_{\mathrm{HXB} 2}$ viral DNA was used as a template. In the first-round PCR, the LTR-Tag-F and LTR-R primers were used and the second-round PCR was performed using the Tag-F and LTR-R primers. The standard linear curve was in the range of $5 \mathrm{ng}$ to $0.25 \mathrm{fg}(R=0.99)$. DNA samples were assayed with quadruplets of each sample (Additional file 3, Fig. S2). For further experimental details, see Rosenbluh et al. [23] see also [45]. The cell equivalents in the sample DNA were calculated based on amplification of the $18 \mathrm{~S}$ gene by real-time PCR as described in Field et al. [46].

\section{Quantitative determination of total viral DNA copies}

Total viral DNA was estimated using SYBR Green realtime quantitative PCR at $12 \mathrm{~h}$ post-infection from the total extract of infected cells. DNA was isolated by the phenol-chloroform method. Briefly, DNA samples $(1 \mu \mathrm{g})$ were added to $95 \mu$ l containing $1 \times$ Hot-Rescue Real Time PCR Kit-SG (Diatheva s.r.l, Fano, Italy), and 100 $\mathrm{nM}$ of each primer-binding-site primer: $\mathrm{F} 5$ ( $5^{\prime}$ primer, $5^{\prime}$-TAGCAGTGGCGCCCGA- $3^{\prime}$ ) and R5 ( $3^{\prime}$ primer, $5^{\prime}$ TCTCTCTCCTTCTAGCCTCCGC -3'). All amplification reactions were carried out in an ABI Prism 7700 Sequence Detection System: one cycle at $95^{\circ} \mathrm{C}$ for $10 \mathrm{~min}$, followed by 45 cycles of $15 \mathrm{~s}$ at $95^{\circ} \mathrm{C}$ and $35 \mathrm{~s}$ at $68^{\circ} \mathrm{C}$. In each PCR run, three replicates were performed. All other details are exactly as described in Casabianca et al. [47].

\section{HIV-1 titration by multinuclear activation of a} galactosidase indicator (MAGI) assay

Quantitative titration of HIV-1 was carried out using the MAGI assay, as described previously [36]. Briefly, TZMb1 cells were grown in 96-well plates at $10^{4}$ cell/well and incubated for $12 \mathrm{~h}$ at $37^{\circ} \mathrm{C}$. Peptides were then added and after an additional $2 \mathrm{~h}$ of incubation, the cells were infected with $50 \mu \mathrm{l}$ of serially diluted HIV-1. Cultured cells were fixed 2 days post-infection and $\beta$-galactosidase was estimated $[23,48,49]$. Blue cells were counted under a light microscope at $200 \times$ magnification. It should be noted using this assay system may results in slightly higher titer of virus due to leakiness.

\section{Quantitative estimation of HIV-1 infection by determination of extracellular p24}

The amount of $\mathrm{p} 24$ protein was estimated in the cell medium exactly as described previously [23].

All experiments were repeated three to four times and the differences between the obtained results never exceeded $\pm 10 \%$.

\section{Additional material}

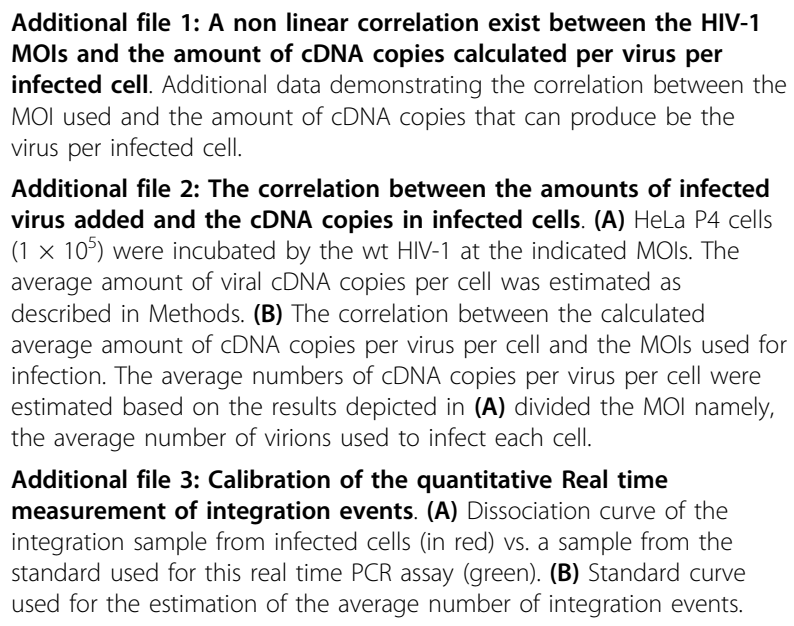

Additional file 2: The correlation between the amounts of infected virus added and the cDNA copies in infected cells. (A) HeLa P4 cells $\left(1 \times 10^{5}\right)$ were incubated by the wt HIV-1 at the indicated MOls. The average amount of viral cDNA copies per cell was estimated as described in Methods. (B) The correlation between the calculated average amount of cDNA copies per virus per cell and the MOls used for infection. The average numbers of cDNA copies per virus per cell were estimated based on the results depicted in (A) divided the $\mathrm{MOI}$ namely, the average number of virions used to infect each cell.

Additional file 3: Calibration of the quantitative Real time measurement of integration events. (A) Dissociation curve of the integration sample from infected cells (in red) vs. a sample from the standard used for this real time PCR assay (green). (B) Standard curve used for the estimation of the average number of integration events.

\section{Acknowledgements}

This work was supported by the Israeli Science Foundation (to A Loyter) and by a starting grant from the European Research Council (ERC) (to AF).

\section{Author details}

'Department of Biological Chemistry, The Alexander Silberman Institute of Life Sciences; The Hebrew University of Jerusalem, Safra Campus, Givat Ram, Jerusalem 91904, Israel. ${ }^{2}$ Institute of Chemistry; The Hebrew University of Jerusalem, Safra Campus, Givat Ram, Jerusalem 91904, Israel.

\section{Authors' contributions}

AL designed and performed the experiments, analyzed data and contributed to writing the paper; $\mathrm{ZH}$ performed peptide synthesis and purification; AF designed the study, and contributed to the writing; AL designed the study, contributed to the writing of the paper and coordinated the study. All authors have read and approved the manuscript.

\section{Competing interests}

The authors declare that they have no competing interests.

Received: 7 May 2010 Accepted: 2 August 2010

Published: 2 August 2010 


\section{References}

1. Busschots K, Vercammen J, Emiliani S, Benarous R, Engelborghs Y, Christ F, Debyser Z: The interaction of LEDGF/p75 with integrase is lentivirusspecific and promotes DNA binding. J Biol Chem 2005, 280:17841-17847.

2. Cherepanov P, Ambrosio AL, Rahman S, Ellenberger T, Engelman A Structural basis for the recognition between HIV-1 integrase and transcriptional coactivator p75. Proc Natl Acad Sci USA 2005 102:17308-17313.

3. Cherepanov P, Devroe E, Silver PA, Engelman A: Identification of an evolutionarily conserved domain in human lens epithelium-derived growth factor/transcriptional co-activator p75 (LEDGF/p75) that binds HIV-1 integrase. J Biol Chem 2004, 279:48883-48892.

4. Emiliani S, Mousnier A, Busschots K, Maroun M, Van Maele B, Tempe D, Vandekerckhove L, Moisant F, Ben-Slama L, Witvrouw M, et al: Integrase mutants defective for interaction with LEDGF/p75 are impaired in chromosome tethering and HIV-1 replication. J Biol Chem 2005 280:25517-25523.

5. Llano M, Saenz DT, Meehan A, Wongthida P, Peretz M, Walker WH, Teo W Poeschla EM: An essential role for LEDGF/p75 in HIV integration. Science 2006, 314:461-464.

6. Maertens G, Cherepanov P, Pluymers W, Busschots K, De Clercq E, Debyser $Z$, Engelborghs $Y$ : LEDGF/p75 is essential for nuclear and chromosomal targeting of HIV-1 integrase in human cells. J Biol Chem 2003, 278:33528-33539.

7. Botbol Y, Raghavendra NK, Rahman S, Engelman A, Lavigne M: Chromatinized templates reveal the requirement for the LEDGF/p75 PWWP domain during HIV-1 integration in vitro. Nucleic Acids Res 2008, 36:1237-1246.

8. Llano M, Vanegas M, Hutchins N, Thompson D, Delgado S, Poeschla EM: Identification and characterization of the chromatin-binding domains of the HIV-1 integrase interactor LEDGF/p75. J Mol Biol 2006, 360:760-773.

9. Shun MC, Botbol Y, Li X, Di Nunzio F, Daigle JE, Yan N, Lieberman J, Lavigne $M$, Engelman A: Identification and characterization of PWWP domain residues critical for LEDGF/p75 chromatin binding and human immunodeficiency virus type 1 infectivity. J Virol 2008, 82:11555-11567.

10. Llano M, Vanegas M, Fregoso O, Saenz D, Chung S, Peretz M, Poeschla EM: LEDGF/p75 determines cellular trafficking of diverse lentiviral but not murine oncoretroviral integrase proteins and is a component of functional lentiviral preintegration complexes. J Virol 2004, 78:9524-9537.

11. Maertens G, Cherepanov P, Debyser Z, Engelborghs Y, Engelman A: Identification and characterization of a functional nuclear localization signal in the HIV-1 integrase interactor LEDGF/p75. J Biol Chem 2004, 279:33421-33429.

12. De Rijck J, Vandekerckhove L, Gijsbers R, Hombrouck A, Hendrix J, Vercammen J, Engelborghs Y, Christ F, Debyser Z: Overexpression of the lens epithelium-derived growth factor/p75 integrase binding domain inhibits human immunodeficiency virus replication. J Virol 2006, 80:11498-11509.

13. Rahman S, Lu R, Vandegraaff N, Cherepanov P, Engelman A: Structurebased mutagenesis of the integrase-LEDGF/p75 interface uncouples a strict correlation between in vitro protein binding and HIV-1 fitness. Virology 2007, 357:79-90.

14. Levin A, Rosenbluh J, Hayouka Z, Friedler A, Loyter A: Integration of HIV-1 DNA is regulated by interplay between viral Rev and cellular LEDGF/p75 proteins. Mol Med 2010, 16:34-44.

15. Pollard WW, Malim MH: The HIV-1 Rev protein. Annu Rev Microbiol 1998 52:491-532.

16. Iyer SR, Yu D, Biancotto A, Margolis LB, Wu Y: Measurement of human immunodeficiency virus type 1 preintegration transcription by using Rev-dependent Rev-CEM cells reveals a sizable transcribing DNA population comparable to that from proviral templates. J Virol 2009, 83:8662-8673

17. Levin A, Hayouka Z, Brack-Werner R, Volsky DJ, Friedler A, Loyter A: Novel regulation of HIV-1 replication and pathogenicity: Rev inhibition of integration. Protein Eng Des Sel 2009, 22:753-763.

18. Levin A, Hayouka Z, Friedler A, Loyter A: Nucleocytoplasmic shuttling of HIV-1 integrase is controlled by the viral Rev protein. Nucleus 2010, 1 [http://www.landesbioscience.com/journals/nucleus/article/11300/].

19. Wu Y: HIV-1 gene expression: lessons from provirus and non-integrated DNA. Retrovirology 2004, 1:13
20. Wu Y, Marsh JW: Early transcription from nonintegrated DNA in human immunodeficiency virus infection. J Virol 2003, 77:10376-10382.

21. Levin A, Hayouka Z, Friedler A, Loyter A: Transportin 3 and importin $\alpha$ are required for effective nuclear import of HIV-1 integrase in virus-infected cells. Nucleus 2010, 1[http://www.landesbioscience.com/journals/nucleus/ article/12903/].

22. Levin A, Hayouka Z, Helfer M, Brack-Werner R, Friedler A, Loyter A: Peptides derived from HIV-1 integrase that bind Rev stimulate viral genome integration. PLOS ONE 2009, 4:e4155.

23. Rosenbluh J, Hayouka Z, Loya S, Levin A, Armon-Omer A, Britan E, Hizi A, Kotler M, Friedler A, Loyter A: Interaction between HIV-1 Rev and Integrase Proteins: A BASIS FOR THE DEVELOPMENT OF ANTI-HIV PEPTIDES. J Biol Chem 2007, 282:15743-15753.

24. Levin A, Hayouka Z, Friedler A, Brack-Werner R, Volsky DJ, Loyter A: A novel role for the viral Rev protein in promoting resistance to Super-infection by Human Immunodeficiency Virus type 1. J Gen Virol 2010, 91:1503-1513.

25. Levin A, Hayouka Z, Helfer M, Brack-Werner R, Friedler A, Loyter A: Stimulation of the HIV-1 Integrase Enzymatic Activity and cDNA Integration by a Peptide Derived from the Integrase Protein. Biopolymers 2010, 93:740-751.

26. Zhao L, O'Reilly MK, Shultz MD, Chmielewski J: Interfacial peptide inhibitors of HIV-1 integrase activity and dimerization. Bioorg Med Chem Lett 2003, 13:1175-1177.

27. Vandekerckhove L, Christ F, Van Maele B, De Rijck J, Gijsbers R, Van den Haute C, Witvrouw M, Debyser Z: Transient and stable knockdown of the integrase cofactor LEDGF/p75 reveals its role in the replication cycle of human immunodeficiency virus. J Virol 2006, 80:1886-1896.

28. Butler SL, Hansen MS, Bushman FD: A quantitative assay for HIV DNA integration in vivo. Nat Med 2001, 7:631-634.

29. Chun TW, Carruth L, Finzi D, Shen X, DiGiuseppe JA, Taylor H, Hermankova M, Chadwick K, Margolick J, Quinn TC, et al: Quantification of latent tissue reservoirs and total body viral load in HIV-1 infection. Nature 1997, 387:183-188.

30. Singh DP, Fatma N, Kimura A, Chylack LT, Shinohara T: LEDGF binds to heat shock and stress-related element to activate the expression of stress-related genes. Biochem Biophys Res Commun 2001, 283:943-955.

31. Jenkins TM, Engelman A, Ghirlando R, Craigie R: A soluble active mutant of HIV-1 integrase: involvement of both the core and carboxyl-terminal domains in multimerization. J Biol Chem 1996, 271:7712-7718.

32. Turlure F, Maertens G, Rahman S, Cherepanov P, Engelman A: A tripartite DNA-binding element, comprised of the nuclear localization signal and two AT-hook motifs, mediates the association of LEDGF/p75 with chromatin in vivo. Nucleic Acids Res 2006, 34:1653-1675.

33. Rosenbluh J, Kapelnikov A, Shalev DE, Rusnati M, Bugatti A, Loyter A: Positively charged peptides can interact with each other, as revealed by solid phase binding assays. Anal Biochem 2006, 352:157-168.

34. Melchior F, Paschal B, Evans J, Gerace L: Inhibition of nuclear protein import by nonhydrolyzable analogues of GTP and identification of the small GTPase Ran/TC4 as an essential transport factor. J Cell Biol 1993, 123:1649-1659.

35. Derdeyn CA, Decker JM, Sfakianos JN, Wu X, O'Brien WA, Ratner L, Kappes JC, Shaw GM, Hunter E: Sensitivity of human immunodeficiency virus type 1 to the fusion inhibitor T-20 is modulated by coreceptor specificity defined by the V3 loop of gp120. J Virol 2000, 74:8358-8367.

36. Kimpton J, Emerman M: Detection of replication-competent and pseudotyped human immunodeficiency virus with a sensitive cell line on the basis of activation of an integrated beta-galactosidase gene. $J$ Virol 1992, 66:2232-2239.

37. Levin A, Hayouka Z, Friedler A, Loyter A: Over expression of the HIV-1 Rev promotes death of non-dividing eukaryotic cells. Virus Genes 2010, 40:341-346.

38. Ratner L, Haseltine W, Patarca R, Livak K, Starcich B, Josephs SF, Doran ER, Rafalski JA, Whitehorn EA, Baumeister $\mathrm{K}$, et al: Complete nucleotide sequence of the AIDS virus, HTLV-III. Nature 1985, 313:277-284.

39. Cullen BR: Use of eukaryotic expression technology in the functional analysis of cloned genes. Methods Enzymol 1987, 152:684-704.

40. Verhoef $\mathrm{K}$, Koper M, Berkhout B: Determination of the minimal amount of Tat activity required for human immunodeficiency virus type 1 replication. Virology 1997, 237:228-236. 
41. Reiser J: Production and concentration of pseudotyped HIV-1-based gene transfer vectors. Gene Ther 2000, 7:910-913.

42. Iordanskiy S, Zhao Y, Dubrovsky L, lordanskaya T, Chen M, Liang D, Bukrinsky M: Heat shock protein 70 protects cells from cell cycle arrest and apoptosis induced by human immunodeficiency virus type 1 viral protein R. J Virol 2004, 78:9697-9704.

43. Kramer-Hammerle S, Ceccherini-Silberstein F, Bickel C, Wolff H, Vincendeau M, Werner T, Erfle V, Brack-Werner R: Identification of a novel Rev-interacting cellular protein. BMC Cell Biol 2005, 6:20

44. Yamamoto N, Tanaka C, Wu Y, Chang MO, Inagaki Y, Saito Y, Naito T, Ogasawara H, Sekigawa I, Hayashida Y: Analysis of human immunodeficiency virus type 1 integration by using a specific, sensitive and quantitative assay based on real-time polymerase chain reaction. Virus Genes 2006, 32:105-113.

45. Zhao WL, Feng D, Wu J, Sui SF: Trichosanthin inhibits integration of human immunodeficiency virus type 1 through depurinating the longterminal repeats. Mol Biol Rep 2010, 37:2093-2098.

46. Field FJ, Born E, Murthy S, Mathur SN: Polyunsaturated fatty acids decrease the expression of sterol regulatory element-binding protein-1 in CaCo-2 cells: effect on fatty acid synthesis and triacylglycerol transport. Biochem J 2002, 368:855-864.

47. Casabianca A, Gori C, Orlandi C, Forbici F, Federico Perno C, Magnani M: Fast and sensitive quantitative detection of HIV DNA in whole blood leucocytes by SYBR green I real-time PCR assay. Mol Cell Probes 2007, 21:368-378.

48. Buzon MJ, Dalmau J, Puertas MC, Puig J, Clotet B, Martinez-Picado J: The HIV-1 integrase genotype strongly predicts raltegravir susceptibility but not viral fitness of primary virus isolates. AIDS 2010, 24:17-25.

49. Douglas JL, Viswanathan K, McCarroll MN, Gustin JK, Fruh K, Moses AV: Vpu directs the degradation of the human immunodeficiency virus restriction factor BST-2/Tetherin via a \{beta\}TrCP-dependent mechanism. J Virol 2009, 83:7931-7947.

doi:10.1186/1743-422X-7-177

Cite this article as: Levin et al:: Peptides derived from the HIV-1 integrase promote HIV-1 infection and multi-integration of viral CDNA in LEDGF/p75-knockdown cells. Virology Journal 2010 7:177.

\section{Submit your next manuscript to BioMed Central and take full advantage of:}

- Convenient online submission

- Thorough peer review

- No space constraints or color figure charges

- Immediate publication on acceptance

- Inclusion in PubMed, CAS, Scopus and Google Scholar

- Research which is freely available for redistribution

Submit your manuscript at www.biomedcentral.com/submit
Biomed Central 